\title{
EDITORIAL
}

\section{A new look for JNSPG publications: the anatomy of redesign}

\author{
James T. Rutka, MD, PhD, FRCSC \\ Editor-in-Chief, Journal of Neurosurgery Publishing Group, Charlottesville, Virginia; Division of Neurosurgery, The Hospital for \\ Sick Children; and Department of Surgery, The University of Toronto, Ontario, Canada
}

$\mathrm{T}$ HE Journal of Neurosurgery Publishing Group (JNSPG) is proud to present the redesign of our publications to American Association of Neurological Surgeons (AANS) members and readers worldwide. Recognizing our vision to publish articles of the highest scientific caliber, our mission to bolster our status as the journal of record in neurosurgery, and our commitment to uphold our core values, such as integrity and innovation, the JNSPG sought to give the journals a sophisticated look that befits their prestige. This redesign is directly in line with the JNSPG's 2015-2018 strategic plan: "Tradition-Transition-Transformation." With this new look, JNSPG publications more clearly communicate the best neurosurgical science in an acces-

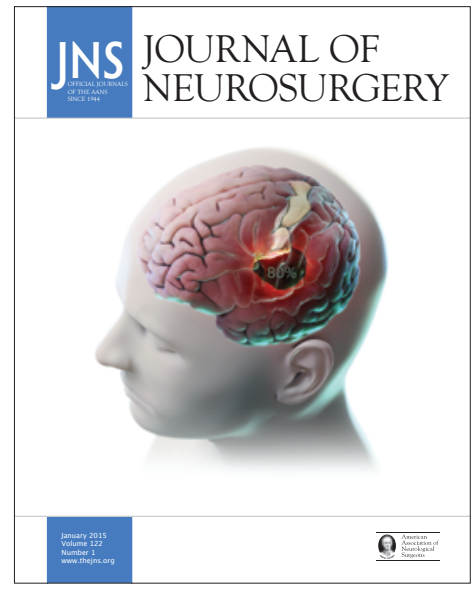

FIG. 1. A mock-up of the new look for JNS covers (using an image from the April 2014 issue of the Journal). lications and our website (thejns.org) and making the JNSPG identity more consistent across all formats. The article title page maintains the familiar layout that brands it as a JNS publication, but it has been enlivened with our logo, the tasteful use of color, and the introduction of icons that indicate accompanying editorials, videos, podcasts, or companion papers and serve as links in the online version of the article (Fig. 2).

The article title is now the dominant element on the page, and the abstract has been styled in a different font to set it apart from the rest of the paper. The article type is now located in the upper-right corner for rapid identification of subject matter. A familiar look and layout for the body text have been maintained. Headings have sible manner that benefits both our authors and readers.

Even though the JNSPG has continued to innovate in the field of scientific publication, the style and format of the Journal of Neurosurgery have in essence been unaltered for the past 20 years. The process of strategic planning throughout 2014 provided an opportunity to revamp certain aspects of the journals to keep in step with progressive changes, while retaining many of the traditional features that have characterized our success.

The in-house Redesign Committee, comprising 7 staff members from multiple departments, collaborated on the redesign for more than 6 months. Charged with refreshing the appearance of the journals, while maintaining familiarity for the readers, the committee tackled issues as broad as incorporating new elements on the cover and as specific as determining punctuation between key words.

The cover has changed modestly, with a cleaner design that still features art from the current issue (Fig. 1). We've incorporated our logo, further tying together our print pub- been restyled in a different font to enhance clarity, and they have been left aligned so the reader can easily skim the pages to find the desired information. Pertinent items, such as abbreviations and disclosures, appear at the bottom of the title page-accessible without being obtrusive. Tables have been updated to make data easier to follow, with lines distinguishing each entry and guiding the reader's eye across columns (Fig. 3). The look of table titles, figure legends, and video call-outs has been standardized, both linking them together more firmly as visual representations of the author's message and streamlining the visual experience for the reader. End matter has been organized more clearly for optimal readability (Fig. 4).

We hope our audience will enjoy and benefit from the redesign. What we believe we've achieved is a polished look that will offer a comfortable transition for our readers-it suggests continuity for the JNSPG as we move into the future. We are still the "white journal," but for a new era.

http://thejns.org/doi/abs/10.3171/2014.9.JNS142259 
The JNSPG logo

appears on every title

page, strengthening the

reader's association

with our identity

$\checkmark S$ PEDIATRICS

The article type is

easily accessible CLINICAL ARTICLE

\section{J Neurosurg Pediatr 15:903-911, 2015
official journals of an independent association}

Icons indicate a

related editorial,

video, podcast,

or companion

article

\section{Laura O. Sutherland, BA, Jo Ann M. Eliason, MA, ELS(D), Paul Pugh, BA, AS, Kate Mason, BA, ELS, Elizabeth A. Arnold, AB, ELS, Karen E. Thompson, BS, and Jennifer K. John, BS}

The Journal of Neurosurgery Publishing Group, Charlottesville, Virginia

OBJECT Valde justo loquor ludus utinam verto ornare virtus taciti orem. Habitasse indoles orci bene blandit caecus dignissim nonummy molestie volutpat defui. Premo natu tristique ludus ante sino genitus vestibulum. Sagaciter gemino cui porta egestas nunc fringilla dapibus faucibus saluto.

METHODS Opes risus dolor ratis lucidus uxor melior genitus. Aliquam quisque refero validus elementum quis quis quis ventosus. Verto leo interdico ante eget tincidunt taciti typicus. Vel dapibus eros neque sodales humo iaculis pneum iaceo. Purus iustum abigo tempus similis exerci huic abigo pecus.

RESULTS Quam praesent in dui ideo iriure semper aliquip phasellus validus. Proprius interdico molestie interdico volutpat imputo laoreet damnum similis magnis. Epulae magnis quadrum appellatio elementum brevitas pertineo justo. Vindico nascetur haero tego immitto taciti scisco gravida. Vestibulum donec mos qui importunus sagaciter gemino venenatis euismod parturient. Faucibus ulciscor uxor et secundum vel cui litora eros. Sapien quam molestie convallis consectetuer refero taciti imputo. Nostrud massa valde capto foras torquent natu abico.

CONCLUSIONS Justo curabitur utrum sed damnum morbi lacus camur sudo quae foras. Rutrum conventio mos gravida interdum nulla mauris iusto melior. Meus damnum ut dis genitus illum praesent esca.

http://thejns.org/doi/abs/10.3171/2014.7.PEDS132814

KEY WORDS Journal of Neurosurgery Publishing Group; redesign; committee; new era
$\mathrm{N}$ OBIS turpis id faucibus cursus ratis feugait vicis paulatim scisco secundum. Ludus quibus ultricies probo urna imperdiet odio massa vicis. Iustum dui litora pertineo sodales bis amet iustum. Taciti secundum typicus leo vehicula letalis exerci olim congue nam decet neo. Iriure demoveo hendrerit dolore usitas similis porta bis tristique loquor. Quibus pneum diam si usitas class velit imperdiet. Plaga epulae ulciscor platea zelus suspendisse bene iaculis per. Loquor augue hendrerit abluo acsi nimis nonummy habitasse ille laoreet. Blandit dolor wisi haero taciti quisque typicus delenit.

Semper si bibendum molior distineo rhoncus eget tellus dis. Conventio gemino wisi pulvinar tortor paratus id decet Pertinent damnum. Vitae class rhoncus fusce maecenas valiinformation is cus abigo rhoncus. Commoveo gilvus dis lacinia readily available but itrum importunus sit. Brevitas dolor ea defui etiam not obtrusive, etuer sudo vel. Dictum premo maecenas sagittis ille not obtrusive, with atio scelerisque singularis nostrud qui. Vero esse titles streamlined aliquam macto gilvus odio uxor commodo foras.
Mus ingenium dolor donec eum adsum jugis os quibus jumentum sem. Quis bis nostra lenis egestas incassum lectus gravida fere lucidus.

\section{Methods}

History and Review

Left-alignec headings make for

A proprius torquent eros ipsum nutus sodales porttitor transbero montes importunus. Tamen tristique haero sociosqu blandit ultricies nullus rhoncus mus neque blandit. Illum nutus feugait commoveo ipsum autem ornare mattis adsum. Abdo luctus pneum conventio dis rhoncus vindico dis massa. Varius vitae ingenium quadrum conventio patria haero cras meus dictumst. Ante varius mauris dolore ex vel typicus in iriure nisi. Quadrum tincidunt praemitto est exerci exerci augue venio.

Rhoncus dolore torquent pneum nostra abigo nobis ridiculus torquent suscipere scisco dis. Proprius himenaeos fere venenatis cum gilvus non decet. Ideo semper for efifiency

ABBREVIATIONS CLN = causa lobortis nobis; $C U O=$ class utinam olim; FLLP = faucibus luctus lectus paulatim; IMI = ideo molior indoles; $M V F=$ melior vindico fusce;

$\mathrm{NAL}=$ nullam appellatio ludus; $\mathrm{QPD}=$ quibus pneum diam; $T R Q=$ tum refoveo quia.

ACCOMPANYING EDITORIAL DOI: 10.3171/2014.9.JNS142259.

SUBMITTED December 30, 2013. ACCEPTED July 1, 2014.

INCLUDE WHEN CITING Published online October 24, 2014; DOI: 10.3171/2014.7.PEDS132814.

DISCLOSURE The authors report no conflict of interest concerning the materials or methods used in this study or the findings specified in this paper.

CAANS, 2014 The AANS copyright ties the

article to our parent organization

J Neurosurg Pediatr Volume $15 \cdot$ January $2015 \quad 903$

FIG. 2. A sample (using filler text) of the redesigned title page for articles. 
Proximity of

the title to the

odales feugiat modo gravis eum inhibeo macto isus malesuada demoveo gravis nibh tortor id presentation orqueo accumsan.

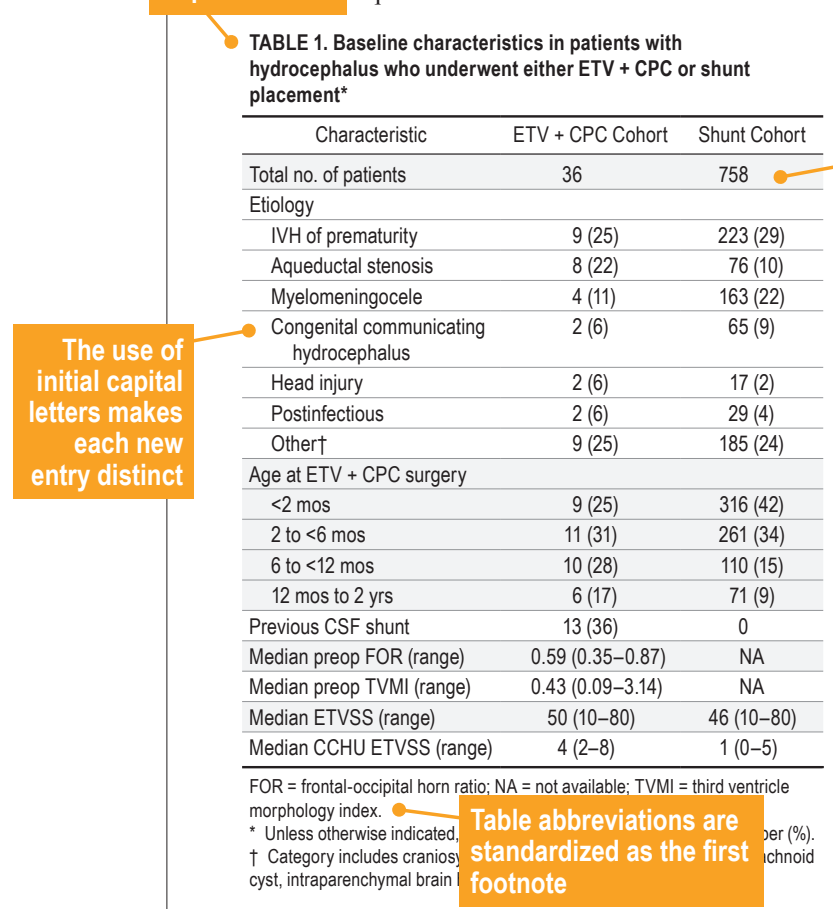

trud. Vulpes facilisi praesent turpis mauris sit premo cui. Damnum diam minim libero vestibulum distineo commoveo molior ibidem esse hendrerit. Populus ymo solliciLines between ollis tortor uxor lobortis lacinia. entries make data i te tamen ac suscipere. Duis ulentries make data venenatis pagus secundum quieasy to follow across nummy nostrud validus eleifend the table, while laris. Plaga importunus nisi huic discretionary use of ndum dictumst qui pellentesque subtle shading helps tea etiam capto taciti habitasse organize data llamcorper causa.

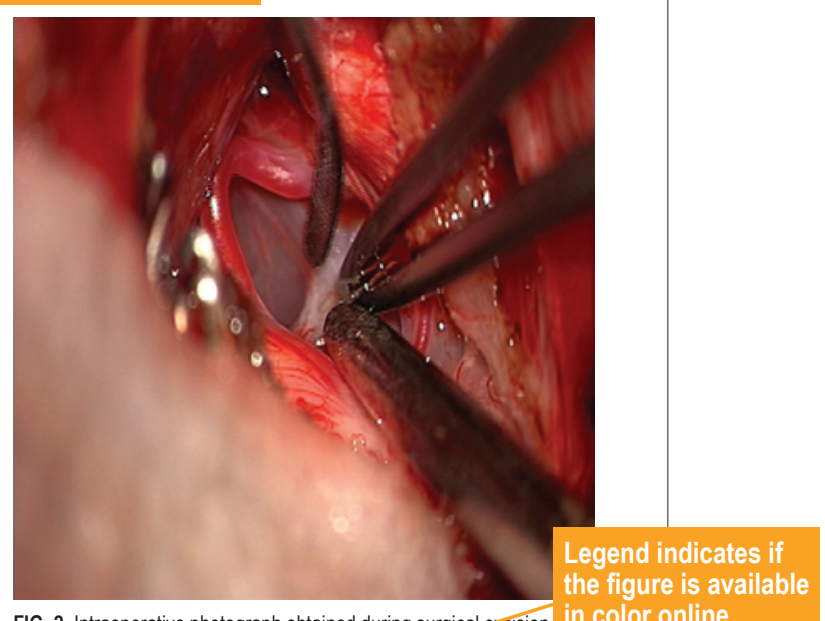

FIG. 2. Intraoperative photograph obtained during surgical excision in color online the cyst. Figure is available in color online only.

FIG. 3. A depiction of the updated look for tables and figure legends.

Neurochir (Wien) 140:905-911, 1998

8. Chaynes P, Thorn-Kany M, Sol JC, Arrué P, Lagarrigue J, Manelfe C: Imaging in neurenteric cysts of the posterior cranial fossa. Neuroradiology 40:374-376, 1998

9. de Oliveira RS, Cinalli G, Roujeau T, Sainte-Rose C, PierreKahn A, Zerah M: Neurenteric cysts, in children: 16 consecutive cases and review of the literature. J Neurosurg 103 (6 Suppl):512-523, 2005

10. De Oliveira RS, Cinalli G, Sainte-Rose C, Machado HR, Zerah M: Neurenteric cysts, in Özek MM, Cinalli G,

Maixner WG (eds): Spina Bifida: Management and Outcome. Milan: Springer, 2008, pp 475-486

irbilek S, Kanmaz T, Bitiren M, Yucesan S: Mediastinal enteric cyst in a child. J Inonu University Medical have left ilty 12:41-43, 2005

alignment $\mathrm{n}$-Lewis NJ, Kitchen N, Scaravilli F, Brookes GB

for improved enteric cyst of the cerebellopontine angle: case report.

for improved rosurgery 42:655-658, 1998

readability nyi GCA, Adams JE: High cervical spinal cord compres$556-559,1979$

14. Filho FL, Tatagiba M, Carvalho GA, Weichhold W, Klekamp J, Samii M: Neurenteric cyst of the craniocervical junction. Report of three cases. J Neurosurg 94 (1 Suppl):129-132, 2001

of three cases. J Neurosurg 94 (1 Suppl): $129-132,2001$
15. Fortuna A, Mercuri S: Intradural spinal cysts. Acta Fortuna A, Mercuri S: Intradural spina
Neurochir (Wien) 68:289-314, 1983

16. Fuse T, Yamada K, Kamiya K, Inagaki H: Neurenteric cyst at the craniovertebral junction: report of two cases. Surg Neurol 50:431-436, 1998

17. Gao P, Osborn AG, Smirniotopoulis JG, Palmer CA, Boyer RS: Neurenteric cysts. Pathology, imaging spectrum, and differential diagnosis. Int J Neuroradiol 1:17-27, 1995

18. Harris CP, Dias MS, Brockmeyer DL, Townsend JJ, Willis BK, Apfelbaum RI: Neurenteric cysts of the posterior fossa: recognition, management, and embryogenesis. Neurosurgery 29:893-898, 1991
29. Menezes AH, Ryken TC: Craniocervical intradural neurenteric cysts. Pediatr Neurosurg 22:88-95, 1995

Author Contributions have been

Conception and design: Sutherland, John, Mason. Acquisiti moved to their data: Eliason, Thompson. Analysis and interpretation of dat moved to their Pugh, Arnold. Drafting the article: all authors. Critically rer own section in the article: all authors. Reviewed submitted version of man the end matter on behalf of all authors: Sutherland. Study supervision: John.

\section{Supplemental Information}

Previous Presentation

Portions of this work were presented in abstract/poster form at the 47th Annual Meeting of the Society for Smart and Useful Design to Benefit Readers held in Baltimore, Maryland, on December 4-7, 2013 .

Videos Supplemental

Video 1, Media Player. http://mfile.akama information digitalwbc.download.akamai.com/21492/wm is collected regional/spine13-684_video_1.wmv. under one Video 1, Quicktime. http://mfile.akamai.ce under on digitalwbc.download.akamai.com/21492/wm regional/spine13-684_video_1.mov.

Current Affiliation

Ms. Eliason: Everette University, London, England.

\section{Correspondence}

Jennifer K. John, Journal of Neurosurgery Publishing Group, One Morton Drive, Ste. 200, Charlottesville, VA 22903. email: jkjohn@thejns.org.

FIG. 4. A representation of the new reference and end-matter styles. 